\title{
REIT modified duration and convexity
}

\author{
P. Pattitoni ${ }^{1} \cdot$ B. Petracci $^{* *} \cdot$ M. Spisni ${ }^{2}$ \\ ${ }^{1}$ Department of Management, University of Bologna, Italy and The Rimini Centre for Economic Analysis \\ (RCEA), Rimini, Italy \\ 2 Department of Management, University of Bologna, Italy
}

Received: 12 July 2012

Revised: 3 September 2012

Accepted: 13 September 2012

\begin{abstract}
Listed Real Estate Investment Trusts (REITs) share several characteristics with bonds. Modified duration and convexity - interest rate risk measures generally applied in bond analyses - could therefore be natural candidates to measure the REIT price sensitivity to interest rate changes. In this paper, we propose a theoretical model that relates the REIT price changes to interest rate fluctuations. Then, we test this model empirically using data from all the 22 Italian listed REITs in the time period 2007-09. Our results show that the relationship between REIT price changes and interest rate variations is, indeed, nonlinear and significant even after market price fluctuations are taken into account. Estimates of modified duration and convexity based on historical data are provided for our sample of REITs.
\end{abstract}

Keywords: REIT, modified duration, convexity

JEL Classification Codes: G23

\section{Introduction}

Listed Real Estate Investment Trusts (REITs) are widespread financial instruments that convoy investor savings toward the real estate industry (Swanson et al., 2002). Fixed maturity REITs have some similarities with bonds: they generally pay a rather stable stream of cash flows during their life and a larger amount - the Net Asset Value (NAV) - at a predefined maturity. ${ }^{1}$

Given these similarities between REITs and bonds, Modified Duration (MD) and Convexity $(\mathrm{CX})$ - the most common interest rate risk measures applied in bond analyses

\footnotetext{
* Corresponding author. E-mail: barbara.petracci@unibo.it.

Citation: Pattitoni, P., B. Petracci and M. Spisni (2012) REIT modified duration and convexity, Economics and Business Letters, 1(3), 1-7.

${ }^{1}$ Sometimes the disposal of assets is gradual over time.
} 
(Fabozzi, 1999) - can also be used to measure the REIT price sensitivity to interest rate fluctuations. This sensitivity is likely to exist for several reasons. One such a reason is that REIT underlying assets are real estate properties whose prices are influenced by interest rate changes: real estate investments (and the real estate market, in general) strongly rely on borrowed funds and, thus, are interest rate driven.

MD and CX have long been used as measures of bond interest rate risk (Kritzman, 1992; Ortiz, 2008; Smith, 2010). Several studies have, however, tried to extend the concepts of MD and CX to asset classes other than bonds, e.g. stocks (Leibowitz et al., 1989; Johnson, 1990; Azar, 2007). Furthermore, a number of researches in the real estate economics literature, although with different nuances, have estimated the sensitivity of REIT returns to interest rate changes finding conflicting results. On the one hand, Chen and Tzang (1988), McCue and Kling (1994), Allen et al. (2000), Swanson et al. (2002), and He et al. (2003) report significant sensitivity of REIT returns to changes in interest rates. On the other hand, Park et al. (1990), Mueller and Pauley (1995), and Li and Wang (1995) find little association between REIT returns and interest rate variations. To the best of our knowledge, however, the role of CX in these latter studies has often been overlooked.

To fill this gap, our study extends the aforementioned literature stream by explicitly accounting for second order effects of interest rate movements on REIT price variations. In particular, we first propose a theoretical model that relates REIT price changes to interest rate and market portfolio price movements. Second, we test this model using data from all the 22 Italian listed REITs in the time period 2007-09. Our results show that the relationship between REIT price variations and interest rate changes is, indeed, nonlinear. This result can help REIT managers and investors immunize their portfolios from interest rate risk. Furthermore, since our results show that interest rate changes are important in explaining REIT price variations, future research could consider MD and CX as additional factors to explain the NAV discount puzzle or for REIT pricing in general (Li and Lei 2011; Pattitoni et al., 2013).

\section{Methods}

In this section, we propose a theoretical model that relates REIT price changes to interest rate and market portfolio price movements. REITs are systematically exposed to interest rate risk in addition to general market risk (which affects all classes of securities). The main reason of this interest rate sensitivity is that REIT underlying assets are real estate properties whose prices are influenced by interest rate changes. The primary real estate market is, in fact, vulnerable to interest rate changes because interest rates affect the cost of financing and investors' required rates of return on investments.

Given the above discussion, we can assume the logarithmic price of a REIT, $p_{R}$, to be an unknown differentiable function of the logarithmic price of the market portfolio, $p_{M}$, and of the interest rate level, $i$. Formally, $p_{R}=p_{R}\left(p_{M}, i\right)$. Expanding $p_{R}=p_{R}\left(p_{M}, i\right)$ in a secondorder Taylor series around some arbitrary value of $p_{M}$ and $i$, we get: 


$$
\begin{aligned}
\Delta p_{R} & =p_{R}\left(p_{M}+\Delta p_{M}, i+\Delta i\right)-p_{R}\left(p_{M}, i\right)= \\
& =\frac{\partial p_{R}\left(p_{M}, i\right)}{\partial p_{M}} \Delta p_{M}+\frac{\partial p_{R}\left(p_{M}, i\right)}{\partial i} \Delta i+ \\
& +\frac{1}{2} \frac{\partial^{2} p_{R}\left(p_{M}, i\right)}{\partial p_{M}^{2}}\left(\Delta p_{M}\right)^{2}+\frac{1}{2} \frac{\partial^{2} p_{R}\left(p_{M}, i\right)}{\partial i^{2}}(\Delta i)^{2}+ \\
& +\frac{\partial^{2} p_{R}\left(p_{M}, i\right)}{\partial p_{M} \partial i} \Delta p_{M} \Delta i+R
\end{aligned}
$$

where all derivatives are evaluated in $p_{M}$ and $i$, with $R$ as the error of approximation to the unknown function.

Historical data can be used to empirically test Equation 1. In particular, define the logarithmic return of a REIT at time $t, r_{R t}$, as the REIT logarithmic price variation between $t$ and $t-1$ $\left(\Delta p_{R t}\right)$ and indicate with $r_{M t}$ and $y_{t}$ the market portfolio logarithmic price variation $\left(\Delta p_{M t}\right)$ and the interest rate change $\left(\Delta i_{t}\right)$ on the same time interval. Then, an estimable model of Equation 1 is:

$$
r_{R t}=\alpha+\beta_{1} r_{M t}+\delta_{1} y_{t}+\beta_{2} r_{M t}^{2}+\delta_{2} y_{t}^{2}+\gamma_{M t} y_{t}+\varepsilon_{t}
$$

where $\varepsilon_{t}$ is a zero mean disturbance term that embodies all factors other than the market return and the interest rate change that may affect REIT returns, and - with the model intercept $\alpha$-the error of approximation to the unknown function. In Equation 2, $\beta_{1}$ and $\beta_{2}$ measure the first and second order REIT price sensitivity to market portfolio price movements $\left(\beta_{1}=\frac{\partial p_{R}\left(p_{M}, i\right)}{\partial p_{M}}, \beta_{2}=\frac{1}{2} \frac{\partial^{2} p_{R}\left(p_{M}, i\right)}{\partial p_{M}^{2}}\right)^{2}, \delta_{1}$ corresponds to the opposite of the REIT MD $\left(\delta_{1}=\frac{\partial p_{R}\left(p_{M}, i\right)}{\partial i}=-\mathrm{MD}\right), \delta_{2}$ approximates (the approximation is due to the fact that we are considering logarithmic REIT prices) the REIT CX $\left(\delta_{2}=\frac{1}{2} \frac{\partial^{2} p_{R}\left(p_{M}, i\right)}{\partial i^{2}} \cong \frac{1}{2} \mathrm{CX}=\delta_{2}+\frac{\delta_{1}^{2}}{2}\right.$ ) and $\gamma$ is a coefficient associated to the interaction effect of market portfolio price and interest rate changes on REIT returns.

\section{Data and Results}

To test our model empirically, we use data from all the 22 Italian listed REITs in the time period 2007-09. We choose this time period to include all the 22 REITs in our sample: not all REITs were listed before 2007 or after 2009. It is worth noting that in the time period 2007-

\footnotetext{
${ }^{2}$ In the literature on the evaluation of mutual funds, $\beta_{2}$ is generally interpreted as a risk adjusted measure of fund managers' market timing ability (Treynor and Mazuy, 1966; Bollen and Busse, 2001).
} 
09 our sample comprises the entire population of Italian listed REITs, for a total of 2288 observations. Given the importance of the real estate sector in Italy, where families are generally characterized by a high propensity for real estate investments, ${ }^{3}$ studying REITs is particularly relevant.

For each REIT, we calculate weekly logarithmic returns. Furthermore, we use an allinclusive Italian market index (Milan Comit Global) to proxy the market portfolio and consider the yields of Italian government bonds with different maturity dates $(2,3,5,7,10$, 15 and 30 years) as proxies for interest rates. All data are from Datastream International.

We simultaneously set up 22 equations (one for each Italian REIT) in the form of Equation 2, through a Seemingly Unrelated Regression (SUR) model. Since each of the 22 equations has the same set of right-hand-side variables, estimating the system by SUR corresponds to applying Ordinary Least Squares (OLS) equation-by-equation. The SUR specification, however, makes performing joint tests of significance of coefficients across equations easier. We show the results of our estimation in Table 1. In particular, we estimate eight SUR models: one model for each bond maturity and an additional model estimated using the first Principal Component (PC) of the interest rate series as explanatory variable. We test the joint significance of all the coefficients $\beta_{1}, \beta_{2}, \delta_{1}, \delta_{2}$ and $\gamma$ (one for each REIT) through $F$ tests. Since we estimate a different $\beta_{1}, \beta_{2}, \delta_{1}, \delta_{2}$ and $\gamma$ for each REIT, we report the average value across the equations of each coefficient as a summary statistic of the broad phenomenon.

Looking at the results in Table 1, it is evident that market portfolio returns strongly influence REIT returns. Specifically, the marginal effect of a market portfolio return variation on REIT returns is nonlinear and depends on the absolute value of $r_{M t}$ (through $\beta_{2}$ ) and $y_{t}$ (through $\gamma$ ): it has the same sign as $r_{M t}$ for the lower values of $r_{M t}$ and $y_{t}$, but it may revert its sign for the higher values of $r_{M t}$ or $y_{t}$. All estimated MDs $\left(-\delta_{1}\right)$ are positive, implying a first order negative effect of interest rate variations on REIT price changes. Estimated MDs are, however, significant only when using interest rates corresponding to long term bond maturities (more than 5 years). Average $\delta_{2} \mathrm{~s}$ are significant in all eight models, but there seems to be some ambiguity in their sign: $\delta_{2}$ is generally positive - implying a convex relationship between REIT logarithmic prices and interest rates - but assumes negative values on average when using 2 and 5 year interest rates or the first PC. Since the actual CX is $\mathrm{CX}=2 \delta_{2}+\delta_{1}^{2}$, however, the only negative $\mathrm{CX}$ is associated with 2 year interest rates. It is important to note that, as shown in Table 2, the first PC accounts for $86 \%$ of the variation of the original interest rate series. Furthermore, since all interest rates enter with a positive sign in the first column of the rotation matrix, the first PC can be thought as describing parallel shifts of the yield curve. A graphical representation of REIT returns against market portfolio returns and (10-year) interest rates is presented in Figure 1.

\footnotetext{
${ }^{3}$ According to a Bank of Italy survey (2009), the real estate division represents $19.5 \%$ of the Italian GDP, $61 \%$ of an Italian family's total assets are represented by real estate investments and the ratio of real estate investments to disposable income is 4 .
} 
Table 1. SUR model estimation

\begin{tabular}{|c|c|c|c|c|c|c|c|c|c|c|c|c|c|c|c|c|}
\hline \multirow{3}{*}{$\begin{array}{c}\text { Maturity } \\
\text { Average } \beta_{1} \\
F \text {-test }\end{array}$} & \multicolumn{2}{|c|}{2 yrs. } & \multicolumn{2}{|c|}{3 yrs. } & \multicolumn{2}{|c|}{5 yrs. } & \multicolumn{2}{|c|}{7 yrs. } & \multicolumn{2}{|c|}{10 yrs. } & \multicolumn{2}{|c|}{15 yrs. } & \multicolumn{2}{|c|}{30 yrs. } & \multicolumn{2}{|c|}{$\overline{1^{\text {st }}} \mathbf{P C}$} \\
\hline & 0.150 & $* * *$ & 0.144 & $* * *$ & 0.153 & $* * *$ & 0.150 & $* * *$ & 0.152 & $* * *$ & 0.154 & $* * *$ & 0.155 & $* * *$ & 0.157 & $* * *$ \\
\hline & 3.774 & & 3.733 & & 3.580 & & 3.259 & & 3.057 & & 3.222 & & 3.336 & & 3.367 & \\
\hline Average $\beta_{2}$ & -0.012 & $* * *$ & -0.014 & $* * *$ & -0.015 & $* * *$ & -0.016 & $* * *$ & -0.016 & $* * *$ & -0.016 & $* * *$ & -0.017 & $* * *$ & -0.015 & $* * *$ \\
\hline$F$-test & 3.527 & & 4.894 & & 4.101 & & 4.049 & & 3.795 & & 4.076 & & 4.674 & & 4.259 & \\
\hline Average $\delta_{1}$ & -0.119 & & -0.105 & & -0.111 & & -0.132 & $* * *$ & -0.131 & $* * *$ & -0.120 & $* * *$ & -0.168 & $* * *$ & -0.138 & $* *$ \\
\hline$F$-test & 0.938 & & 1.041 & & 1.288 & & 1.884 & & 2.276 & & 2.010 & & 2.242 & & 1.569 & \\
\hline Average $\delta_{2}$ & -0.009 & $* * *$ & 0.001 & $*$ & -0.003 & $* * *$ & 0.001 & $* * *$ & 0.004 & $* * *$ & 0.005 & $* * *$ & 0.006 & $* * *$ & -0.001 & $* * *$ \\
\hline$F$-test & 1.939 & & 1.530 & & 2.227 & & 2.751 & & 3.996 & & 3.984 & & 3.706 & & 2.789 & \\
\hline Average $\gamma$ & -0.016 & & -0.012 & $*$ & -0.020 & $* * *$ & -0.022 & $* * *$ & -0.025 & $* * *$ & -0.033 & $* * *$ & -0.044 & $* * *$ & -0.028 & $* * *$ \\
\hline$F$-test & 1.368 & & 1.527 & & 2.470 & & 2.834 & & 3.492 & & 2.943 & & 4.252 & & 2.723 & \\
\hline
\end{tabular}

Table 2. Principal components analysis

\begin{tabular}{|c|c|c|c|c|c|c|c|}
\hline Importance of components & $\mathbf{1}^{\text {st }} \mathbf{P C}$ & $2^{\text {nd }} \mathbf{P C}$ & $\mathbf{3}^{\text {rd }} \mathbf{P C}$ & $4^{\text {th }} \mathrm{PC}$ & $5^{\text {th }} \mathrm{PC}$ & $6^{\text {th }}$ PC & $7^{\text {th }} \mathrm{PC}$ \\
\hline Standard deviation & 2.447 & 0.857 & 0.360 & 0.277 & 0.197 & 0.151 & 0.102 \\
\hline Proportion of variance & 0.856 & 0.105 & 0.018 & 0.011 & 0.006 & 0.003 & 0.002 \\
\hline Cumulative proportion & 0.856 & 0.960 & 0.979 & 0.990 & 0.995 & 0.999 & 1.000 \\
\hline
\end{tabular}


Figure 1. REIT returns (\%), market portfolio returns (\%) and (10-year) interest rate changes (\%)

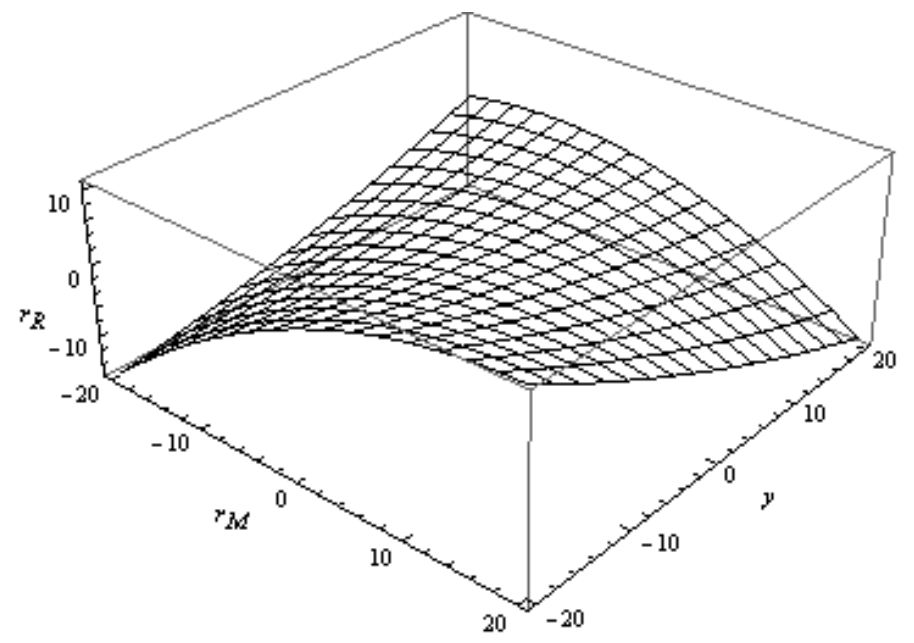

\section{Concluding Remarks}

REITs and bonds have several characteristics in common: similar to bonds, REITs provide investors with a relatively fixed and steady stream of cash flows. The concepts of MD and CX can therefore, be easily extended to REIT interest rate risk analysis.

In this paper, we propose a theoretical model that relates REIT price changes to interest rate variations and test this model empirically using data from all the 22 Italian REITs in the time period 2007-09. Our results show that, after controlling for market portfolio price fluctuations that may influence REIT returns, the relationship between REIT price changes and interest rate variations is nonlinear. Estimated MDs are on average positive, so that an increase in interest rates negatively affects REIT prices. This result is robust to the choice of the interest rate maturity (short and long maturities). The coefficients associated to second order effects of interest rate changes on REIT logarithmic prices are generally positive implying a positive convexity for REITs. The only negative CX is associated with 2 year interest rates.

Our results suggest that estimating MD and CX can help REIT managers and investors immunize their portfolios from interest rate risk, i.e. to manage the REIT price reduction due to adverse interest rate movements. Furthermore, MD and CX can be considered as additional factors to explain the NAV discount puzzle in future research.

\section{References}

Allen, M.T., Madura, J. and Springer, T.M. (2000) Characteristics and the sensitivity of REIT returns, Journal of Real Estate Finance and Economics, 21(2), 141-152.

Azar, S.A. (2007) A duration-based equity premium, Applied Financial Economics Letters, 3(6), 409-414.

Bollen, N. and Busse, J. (2001) On the timing ability of mutual fund managers, Journal of Finance, 56(3), 1075-94.

Chen, K.C. and Tzang, D.T. (1988) Interest rate sensitivity of real estate investment trusts, Journal of Real Estate Research, 3(3), 13-22.

Fabozzi, F.J. (1999) Duration, Convexity, and Other Bond Risk Measures, New Hoep: Wiley.

He, L.T., Webb, J.R. and Myer, F.C.N. (2003) Interest rate sensitivities of REIT returns, International Real Estate Review, 6(1), 1-21. 
Johnson, L.D. (1990) Convexity for equity securities: does curvature matter?, Financial Analysts Journal, 46(5), 70-73.

Kritzman, M. (1992) What practitioners need to know about duration and convexity, Financial Analysts Journal, 48(2), 17-21.

Leibowitz, M.L., Sorensen, E.H., Arnott, R.D. and Hanson, H.N. (1989) A total differential approach to equity duration, Financial Analysts Journal, 45(5), 30-37.

Li, J. and Lei, L. (2011) Determinants and information of REIT pricing, Applied Economics Letters, 18(15), 1501-1505.

Li, Y. and Wang, K. (1995) The predictability of REIT returns and market segmentation, Journal of Real Estate Research, 10(4), 471-482.

McCue, T.E. and Kling, J.L. (1994) Real estate returns and the macroeconomy: some empirical evidence from real estate investment trust data, 1972-1991, Journal of Real Estate Research, 9(3), 277-287.

Mueller, G.R. and Pauley, K.R. (1995) The effect of interest-rate movements on real estate investment trusts, Journal of Real Estate Research, 10(3), 319-326.

Ortiz, C.E., Stone, C.A. and Zissu, A. (2008) Fixed income securities with a zero Macaulay duration: senior life settlements, Applied Financial Economics Letters, 4(3), 205-207.

Park, J., Mullineaux, D. and Chew I. (1990) Are REITs inflation hedges?, Journal of Real Estate Finance and Economics, 3(1), 91-103.

Pattitoni, P., Petracci, B. and Spisni, M. (2013) NAV discount in REITs: the role of expert assessors, Applied Economics Letters, 20(2), 194-198.

Smith, D.J. (2010) Bond portfolio duration, cash flow dispersion and convexity, Applied Economics Letters, 17(17), 1669-1672.

Swanson, Z., Theis, J. and Casey, K.M. (2002) REIT risk premium sensitivity and interest rates, Journal of Real Estate Finance and Economics, 24(3), 319-330.

Treynor, J. and Mazuy, M. (1966) Can mutual funds outguess the market?, Harvard Business Review, 44(4), 131-136. 